\title{
Postoperative Catheter induced bacteriuria in obstetrics and gynaecological cases
}

\author{
Rupakala B. M. ${ }^{1}$, Shivshankar Lasune ${ }^{1 *}$, Prakash R. $^{2}$, R. Nagarathanamma ${ }^{1}$
}

${ }^{1}$ Department of Obstetrics and Gynecology, ${ }^{2}$ Department of Microbiology, Rajarajeswari Medical College and Hospital, Bangalore, Karnataka, India

Received: 28 February 2017

Accepted: 31 March 2017

\section{*Correspondence:}

Dr. Shivshankar Lasune,

E-mail: dreamradio15@gmail.com

Copyright: (C) the author(s), publisher and licensee Medip Academy. This is an open-access article distributed under the terms of the Creative Commons Attribution Non-Commercial License, which permits unrestricted non-commercial use, distribution, and reproduction in any medium, provided the original work is properly cited.

\begin{abstract}
Background: Urinary tract infection is one of most common nosocomial infection and prolonged bladder catheterization is frequent cause. These infections increase hospital stay of patients, morbidity and financial burden. This study was performed to determine rate of catheter induce bacteriuria, most common organisms isolated, rate of bacteriuria associated with duration of catheterization and type of surgery (Elective or Emergency).

Methods: This is prospective observational study done over a period of one year from 2015 January to 2016 January and 599 patients enrolled. The variables studied are rate of catheter induce bacteriuria, most common organisms isolated, rate of bacteriuria associated with duration of catheterization and type of surgery (Elective or Emergency).

Results: Rate of catheter induce bacteriuria was 34.5\%, most common organisms isolated were E. coli, Enteroccocus, MR CONS, Candida albicans, Klebsiella, streptococci. Bacteriuria was $10.5 \%$ when duration of catheterization was less than $12 \mathrm{hrs}$ and $73.9 \%$ when duration of catheterization was more than $36 \mathrm{hrs}$. Also, bacteriuria was more in emergency cases.

Conclusions: It is better to avoid catheterization, duration of catheterization should be reduced so that it reduces catheter induced bacteriuria and associated morbidity, prolonged hospital stay and financial burden.
\end{abstract}

Keywords: Bacteriuria, Postoperative urine culture, Nosocomial, Methicillin resistant coagulase negative staphylococcus

\section{INTRODUCTION}

Bladder drainage by transurethral Foleys catheter is common practice used during and after gynaecological and obstetrical surgery to monitor urine output and prevent post-operative urinary retention. However, its implementation was relatively custom-based, hospital policy based and personal preference-dependent, therefore the duration varies markedly. ${ }^{1-3}$ Routine catheterization up to three days was common after gynaecological surgery. Prolonged catheterization after $24 \mathrm{hrs}$ has minimal benefits in uncomplicated surgery. ${ }^{4}$ It is associated with increased bacterial counts and higher rates of positive urine cultures which concludes UTI is more common in long term catheterization. Duration of catheterization is the most important determinant of bacteriuria. ${ }^{5}$ The daily risk of acquisition of bacteriuria when an indwelling catheter in-situ is 3-7\%. The rate of acquisition is higher for women and older persons. ${ }^{5}$ Catheter acquired urinary tract infection is one of the most common health care acquired infections. ${ }^{6}$ From $60-$ $80 \%$ of hospitalized patients with an indwelling catheter receive antimicrobials, usually for indications other than urinary tract infection. ${ }^{7}$ This intense antimicrobial exposure means antimicrobial resistant organisms are frequently isolated from the urine of catheterized individuals. Urinary catheter acquired infection is usually manifested as asymptomatic bacteriuria (CA-ASB). UTI 
was defined as when one or more organisms are present in quantitative count $>100000 \mathrm{cfu} / \mathrm{ml}$ associated with one or more of dysuria, pain, fever, rigor or sepsis. Asymptomatic bacteriuria was defined as when one or more organisms are present in quantitative count $>100000 \mathrm{cfu} / \mathrm{ml}$ in the absence of symptom.

The most common infecting organism is Escherichia coli. And other organisms are Enteroccocus, MR CONS (methicillin resistant coagulase negative staphylococcus), Candida albicans, Klebsiella species, Streptoccus species and Proteus mirabilis.

\section{METHODS}

This is a prospective observational study included 559 patients undergoing obstetrics and gynaecological surgery, conducted between 2015 January to 2016 January, in Department of Obstetrics and Gynaecology, Rajarajeswari Medical College and Hospital, Bangalore. Ethical committee approval was taken before the start of the study. Informed consent was taken from all patients who enrolled in study.

Routine blood investigations were done. Preoperative urine culture sent before inserting the Foleys catheter, catheter inserted under aseptic precautions 30 minute before start of surgery. Postoperative urine culture sent from the first void after Foleys catheter removal. All patient received spinal anaesthesia except those underwent laparoscopy who received general anaesthesia. Duration of catheter in situ was different in various surgeries ranging from minimum 8 hours to maximum 52 hours. Prophylactic antibiotics were given 30 minute before skin incision and continued for 7-days postoperative.

\section{Inclusion criteria}

All the patients undergoing surgery for obstetrics and gynaecological indications and were catheterised.

\section{Exclusion criteria}

- Pre-operative urine culture positive

- Injury to bladder or ureter during operation

- With other associated complication during operation e.g. hematoma, excessive hemorrhage.

History of neurological disorders, urinary incontinence. Variables assessed are duration of catheter in situ, rate of bacteriuria, type of surgery and most common organism isolated.

\section{RESULTS}

A total of 559 patients enrolled in the study (Table 1), 333 patients underwent Lower segment caesarean section (LSCS) and 226 patients underwent other gynaecological surgeries. 137 patients underwent emergency surgeries while 422 patients underwent elective surgeries. Mean age was $33.39 \pm 12.4$ years. Mean duration of catheterization was $24.28 \pm 13.90$ hrs. $193 \quad(34.5 \%)$ patients had postoperative urine culture positive (Table 4).

$87(63.5 \%)$ patients out of 137 patients underwent emergency surgeries had post-operative culture positive, while $108(25.59 \%)$ patients out of 422 patients underwent elective surgeries had postoperative culture positive. 199 patients had duration of catheterization 1-12 hrs out of which $21(10.5 \%)$ patients had positive postoperative urine culture, 152 patients had duration of catheterization 13-24 out of which 35 (23.1\%) patients had positive postoperative urine culture, 82 patients had duration of catheterization 25-36hrs out of which 45 $(54.9 \%)$ patients had positive postoperative urine culture and 125 patients had duration of catheterization more than 36 hrs out of which $92(73.6 \%)$ patients had positive postoperative urine culture (Table 3 ).

Most common organism isolated was E. coli (Escherichia coli) and other organisms are Enteroccocus, MR CONS, Candida albicans, Klebsiella species, Streptoccus species, Proteus mirabilis, Pseudomonas, Citrobacter freundii and Citrobacter koseri (Table 2).

Table 1: Various surgeries performed.

\begin{tabular}{|lll|}
\hline Name of Surgery & No. of patients & $\%$ \\
\hline LSCS & 333 & 59.6 \\
\hline TAH & 126 & 22.6 \\
\hline VH & 54 & 9.7 \\
\hline Myomectomy & 13 & 2.4 \\
\hline Laparoscopic salpingectomy & 13 & 2.3 \\
\hline LAVH & 10 & 1.8 \\
\hline $\begin{array}{l}\text { Laparoscopic right ovarian } \\
\text { cystectomy }\end{array}$ & 3 & 0.5 \\
\hline Tuboplasty & 3 & 0.5 \\
\hline Laparotomy and cystectomy & 2 & 0.4 \\
\hline $\begin{array}{l}\text { Laparoscopic left ovarian } \\
\text { cystectomy }\end{array}$ & 1 & 0.2 \\
\hline RVF Repair & 1 & 0.2 \\
\hline Total & $\mathbf{5 5 9}$ & $\mathbf{1 0 0 . 0}$ \\
\hline
\end{tabular}

Table 2: Various organisms isolated.

\begin{tabular}{|lll|}
\hline Organism isolated & No. of patients & $\%$ \\
\hline E. coli & 72 & 37.3 \\
\hline Enteroccocus & 59 & 30.6 \\
\hline MR CONS & 26 & 13.5 \\
\hline Candida albicans & 12 & 6.2 \\
\hline Klebsiella & 12 & 6.2 \\
\hline Streptoccus & 4 & 2.1 \\
\hline Proteus mirabilis & 3 & 1.6 \\
\hline Pseudomonas & 3 & 1.6 \\
\hline Citrobacter Koseri & 1 & 0.5 \\
\hline polymicrobial growth & 1 & 0.5 \\
\hline Total & $\mathbf{1 9 3}$ & $\mathbf{1 0 0 . 0}$ \\
\hline
\end{tabular}


Table 3: Duration of catheterization and postoperative urine culture positive rate.

\begin{tabular}{|llll|}
\hline $\begin{array}{l}\text { Duration of } \\
\text { catheter in- } \\
\text { situ in hrs }\end{array}$ & $\begin{array}{l}\text { No. of } \\
\text { patients }\end{array}$ & $\begin{array}{l}\text { No. of post - } \\
\text { operative } \\
\text { positive } \\
\text { culture }\end{array}$ & $\begin{array}{l}\% \text { of } \\
\text { positive } \\
\text { culture }\end{array}$ \\
\hline $1-12$ & 199 & 21 & 10.5 \\
\hline $13-24$ & 152 & 35 & 23.1 \\
\hline $25-36$ & 82 & 45 & 54.9 \\
\hline More than 36 & 125 & 92 & 73.3 \\
\hline
\end{tabular}

Table 4: Postoperative urine culture positive rate.

\begin{tabular}{|lll|}
\hline Postoperative urine culture & No. of patients & $\%$ \\
\hline Positive & 193 & 34.5 \\
\hline Negative & 366 & 65.5 \\
\hline Total & $\mathbf{5 5 9}$ & $\mathbf{1 0 0}$
\end{tabular}

\section{DISCUSSION}

Bladder drainage by transurethral Foleys catheter is common practice used after gynaecological and obstetrical surgery to monitor urine output and prevent post-operative urinary retention. Catheter induce UTI is one of the common health problem, approximately $15 \%$ of nosocomial bacteremia are due to UTI. ${ }^{8}$

In our study catheter induce bacteriuria rate was $34.5 \%$ results were comparable with study done by Stamm WE and Hilton $\mathrm{P}$ were bacteriuria rate was $30 \% .^{9,10}$

In our study, most common organism isolated was $E$. coli results are comparable with study done by B Shrestha et al which shows $E$. coli was most common organism. ${ }^{11}$

In our study rate of bacteriuria was more when duration of catheterization increases, bacteriuria rate was maximum when duration was more than 36hrs, and results were comparable with study done by B Shrestha et al. ${ }^{11}$

Similar study done by S Niveditha et al found catheter induce bacteriuria was more in patients in duration of catheterization was more. ${ }^{12}$

Study done by Hjalmar et al also found catheter induce bacteriuria was more in long term catheterization. ${ }^{2}$

Study by Glavid et al, found that rate of catheter induce bacteriuria was more in patient with long duration of catheterization. $^{13}$

In our study bacteriuria rate was $10.5 \%$ when duration of catheterization was less than $12 \mathrm{hrs}, 23.1 \%$ when duration of catheterization was $13-24 \mathrm{hrs}, 54.9 \%$ when duration of catheterization was $25-36 \mathrm{hrs}$ and $73.9 \%$ when duration was more than $36 \mathrm{hrs}$ and most common organism isolated was E. Coli and results are similar to study done by Shakya YM et al. ${ }^{14}$ In our study, we found catheter induce bacteriuria was also more common in emergency surgeries $(63.5 \%)$ compared with elective surgeries $(25.6 \%)$.

\section{CONCLUSION}

We conclude that catheter induced bacteriuria was more common with emergency cases compared with elective cases. It is better to avoid catheterization wherever possible if not duration of catheterization should be reduced, so that it reduces catheter induced bacteriuria and associated morbidity, prolonged hospital stay and financial burden.

\section{ACKNOWLEDGEMENTS}

Author would like to thanks Dr Nagendra Prasad who always helped him during 3 years of PG course, also author thank his patients who gave consent for study.

Funding: No funding sources

Conflict of interest: None declared

Ethical approval: The study was approved by the Institutional Ethics Committee

\section{REFERENCES}

1. Kamilya G, Seal SL, Mukherji J, Bhattacharyya SK, Hazra A. A randomised controlled trial comparing short versus long-term catheterization after uncomplicated vaginal prolapsed surgery. J Obstet Gynaecol Res. 2010;36(1):154-8.

2. Schiøtz HA, Tanbo TG. Postoperative voiding, bacteriuria and urinary tract infection with Foley catheterization after gynecological surgery. Acta Obstet Gynecol Scand. 2006;85(4):476-81.

3. Wyman A. What time of day should a urethral catheter be removed? J R Soc Med. 1987;80(12):755-6.

4. Pant PR. An effective short duration postoperative catheterization after vaginal hysterectomy and pelvic floor repair. J Institute Medicine. 2007;28(1).

5. Hooton TM, Bradley SF, Cardenas DD, Colgan R, Geerlings SE, Rice JC, et al. Diagnosis, prevention and treatment of catheter-associated urinary tract infection in adults; 2009 international clinical practice guidelines from the Infectious Diseases Society of America. Clin Infect Dis. 2010;50:625-63.

6. Zarb P, Coignard B, Griskevicienne J, Muller A, Vankerckho ven Weist K, Goossens MM, et al. The European Centre for Disease Prevention and Control (ECDC) pilot point prevalence survey of healthcareassociated infections and antimicrobial use. Euro Surveill. 2012;17(46):20316.

7. Tark RP, Maki DG. Bacteriuria in the catheterized patient. What quantitative level of bacteriuria is relevant? N Engl J Med. 1984;311:560-4.

8. Bryan CS, Reynolds KL. Hospital-acquired bactermic urinary tract infection: epidemiology and outcome, J Urol. 1984;132:494-8. 
9. Stamm WE. Guidelines for prevention of catheterassociated urinary tract infection. Ann intern Med. 1975;82:386-90.

10. Hilton P. Bladder drainage: a survey of practices among gynaecologists in the British isles. Br J Obstet Gynecol. 1988:95:1178-89.

11. Shrestha B, Marhatha R, Kayastha S, Jaishi S. Shortterm versus long-term catheterization after vaginal prolapse surgery. Nepal Med Coll J. 2013;15:102-5.

12. Niveditha S, Pramodhini S, Umadevi S, Kumar S, Stephen S. The isolation and the biofilm formation of uropathogens in the patients with catheter associated urinary tract infections (UTIs). J Clin Diagn Res. 2012;6(9):1478-82.

13. Glavind K, Mørup L, Madsen H, Glavind J. A prospective, randomised, controlled trial comparing
3 hour and 24-hour postoperative removal of bladder catheter and vaginal pack following vaginal prolapse surgery. Acta obstetricia et gynecologica Scandinavica. 2007;86(9):1122-5.

14. Shakya YM. A Comparative Study on Bacteriuria Following Short Term Versus Long Term Catheterization After Cesarean Section. J Soc Surgeons Nepal (JSSN). 2015;16(2).

Cite this article as: Rupakala BM, Lasune S, Prakash R, Nagarathanamma R. Postoperative Catheter induced bacteriuria in obstetrics and gynaecological cases. Int J Reprod Contracept Obstet Gynecol 2017;6:1965-8. 